\title{
Visualisasi Data Kependudukan Pada Dinas Kependudukan Dan Pencatatan Sipil Kabupaten Musi Banyuasin
}

\author{
Rica Damayanti Putri1, Alex Wijaya*2 \\ 1,2 Informatics Departement, Bina Darma University, Palembang, Idnonesia \\ Email: 1putridamayantirica@gmail.com, 2allec_wj@yahoo.com
}

\begin{abstract}
Population data from the Department of Population and Civil Registration can be used by other agencies according to the needs of that agency. The Department of Population and Civil Registration uses SIAK (Sistem Informasi Administrasi Kependudukan /Population Administration Information System) for its service processes, the SIAK application is an application made by the Director General of Department of Population and Civil Registration of the Ministry of Home Affairs. The SIAK application still has limited features for operators in the District, for this reason the SIDAK application was created for the utilization of population data in Musi Banyuasin Regency. In this SIDAK application, there is no feature available for visualizing graphical data so that the desired data can be easily analyzed in aggregate data. For the data visualization, the authors took the data from the SIAK database conversion to the SIDAK application. The data taken is the aggregate data on the number of populations, mandatory ID card, birth, death, move, arrival, occupation, religion, education, blood group, marital status, persons with disabilities, age groups. Therefore, we need a tool that capable of visualizing population data using a website in the form of a dashboard system at the Department of Population and Civil Registration. This population data visualization system development uses the Extreme Programming method.
\end{abstract}

Keywords: Visualisasi data, Dashboard System, Website, XP

\section{PENDAHULUAN}

Dalam Undang-Undang Nomor 24 Tahun 2013 Tentang Administrasi Kependudukan dijelaskan bahwa Administrasi Kependudukan adalah rangkaian kegiatan penataan dan penertiban dalam penerbitan dokumen dan Data Kependudukan melalui Pendaftaran Penduduk, Pencatatan Sipil, pengelolaan informasi administrasi kependudukan serta 
Vol. 1, No. 3, September 2020 e-ISSN: 2775-2496

https://journal-computing.org/index.php/journal-cisa/index

pendayaguan hasilnya untuk pelayanan publik dan pembangunan sektor lain. Pengelolaan data kependudukan yang baik sangat dibutuhkan dalam melakukan kegiatan pendataan, pencatatan, dan pelaporannya. Hal ini dilakukan untuk meningkatkan pelayanan, pemantauan data penduduk, dan perencanaan pembangunan. (Supardin et al., 2016).

Dinas Kependudukan dan Pencatatan Sipil Kabupaten Musi Banyuasin melayani pelayanan Administrasi Kependudukan untuk masyarakat menggunakan aplikasi SIAK. Aplikasi SIAK merupakan aplikasi yang dibuat oleh Dirjen Dukcapil Kemendagri RI yang digunakan oleh seluruh Disdukcapil di Indonesia, namun aplikasi ini masih terdapat keterbatasan fitur untuk operator kecamatan, karena operator kecamatan banyak melakukan pelayanan langsung ke masyarakat di kecamatan yang bersangkutan, untuk itulah diperlukan aplikasi SIDAK.

Dinas Kependudukan dan Pencatatan Sipil selain melayani administrasi kependudukan juga sebagai sumber data terupdate perkembangan data kependudukan baik dari jumlah penduduk, agama, pekerjaan, pendidikan, migrasi penduduk dan sebagainya. Dengan adanya visualisasi dalam aplikasi SIDAK ini penulis dapat dimanfaatkan oleh operator kecamatan ataupun stakeholder yang berkepentingan dalam pemanfaatan data seperti pencarian biodata penduduk. Untuk data visualisasinya, penulis mengambil datanya dari hasil konversian database SIAK ke aplikasi SIDAK. Oleh karena itu, diperlukan sistem yang mampu memvisualisasikan data kependudukan pada Dinas Kependudukan dan Pencatatan Sipil Kabupaten Musi Banyuasin. Dengan demikian data kependudukan dapat mudah dimanfaatkan dalam berbagai aspek dalam menunjang pembangunan seperti mengambil keputusan yang lebih tepat untuk peningkatan kualitas pelayanan publik.

\section{METODE PENGEMBANGAN}

Dalam melakukang pengembangan digunakan metode Exteme Programming. Menurut Fatoni \& Dwi dalam (Budiarti \& Risyanto, 2020) Extreme Programming adalah model pengembangan perangkat lunak yang menyederhanakan berbagai tahapan pengembangan sistem menjadi lebih efisien, adaftif dan fleksibel. Menurut Schach dalam (Rusdiana, 2018) Ada beberapa tahapan dalam metode Extreme Programming ini, yaitu : 
Vol. 1, No. 3, September 2020 e-ISSN: 2775-2496

https://journal-computing.org/index.php/journal-cisa/index

1. Perencanaan (Planning)

Perencanaan merupakan tahapan awal untuk memulai penelitian dengan mendefinisikan kebutuhan yang diperlukan, output yang akan dihasilkan, layanan yang akan dikembangkan pada aplikasi, dan fitur serta fungsional dari aplikasi yang akan dikembangkan.

2. Perancangan (Design)

Tahapan ini merupakan bagian dari perancangan aplikasi yang sesuai dengan kebutuhan dari penggunaanya.

3. Pengkodean (Coding)

Tahapan pengkodean merupakan tahapan dalam menyiapkan kode pada software yang dapat digunakan dalam pengembangan aplikasi sehingga dapat menjadi pemecahan masalah.

4. Pengujian (Testing)

Tahapan pengujian merupakan tahapan terakhir untuk menguji layanan atau fitur dan fungsionalitas yang terdapat pada aplikasi yang dibangun. Sehingga dapat diambil kesimpulan dari pengujian yang dilakukan.

\section{RESULTS AND DISCUSSION}

Dari Proses pengembangan menggunakan Exteme Programming dengan empat tahapan utama maka dapat dijelaskan hasil dari pengembangan tersebut yaitu:

\subsection{Menu Login}

Pada menu login ini merupakan halaman untuk masuk ke dalam sistem visualisasi "data kependudukan pada Dinas Kependudukan dan Pencatatan Sipil Kabupaten Musi Banyuasin. Adapun menu login dapat di lihat pada gambar 1 .

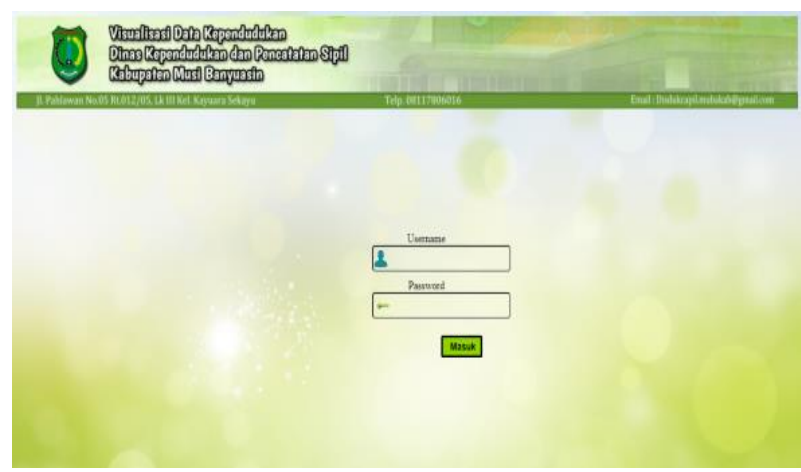

Gambar 1. Desain tampilan login 
Vol. 1, No. 3, September 2020 e-ISSN: 2775-2496

https://journal-computing.org/index.php/journal-cisa/index

\subsection{Menu Dashboard}

Pada menu dashboard ini merupakan halaman awal yang akan ditampilkan pada saat setelah melakukan login pada sistem visualisasi data kependudukan. Dashboard ini menampilkan keseluruhan grafik yang ditampilkan pada sistem. Adapun menu dashboard dapat di lihat pada gambar 2.

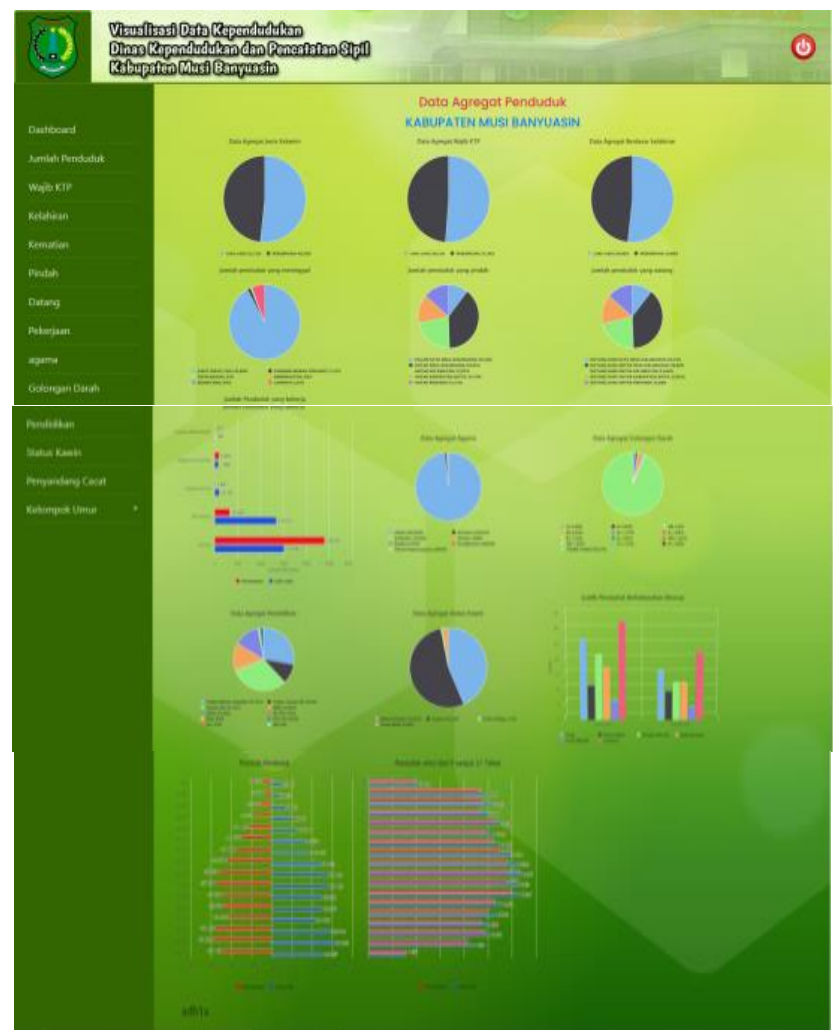

Gambar 2. Desain tampilan dashboard

\subsection{Menu Jumlah Penduduk}

Pada menu jumlah penduduk ini merupakan halaman untuk menampilkan data jumlah penduduk perkecamatan dan perjenis kelamin yang ada pada Dinas Kependudukan dan Pencatatan Sipil Kabupaten Musi Banyuasin berbentuk grafik dan table baik data pada bulan lalu ataupun data bulan sekarang, dalam hal ini tentunya memudahkan pengguna untuk menggunakan data tersebut. "Adapun menu jumlah penduduk ini dapat di lihat pada gambar 3 . 


\section{Journal of Computer and Information Systems Ampera}

Vol. 1, No. 3, September 2020 e-ISSN: 2775-2496

https://journal-computing.org/index.php/journal-cisa/index

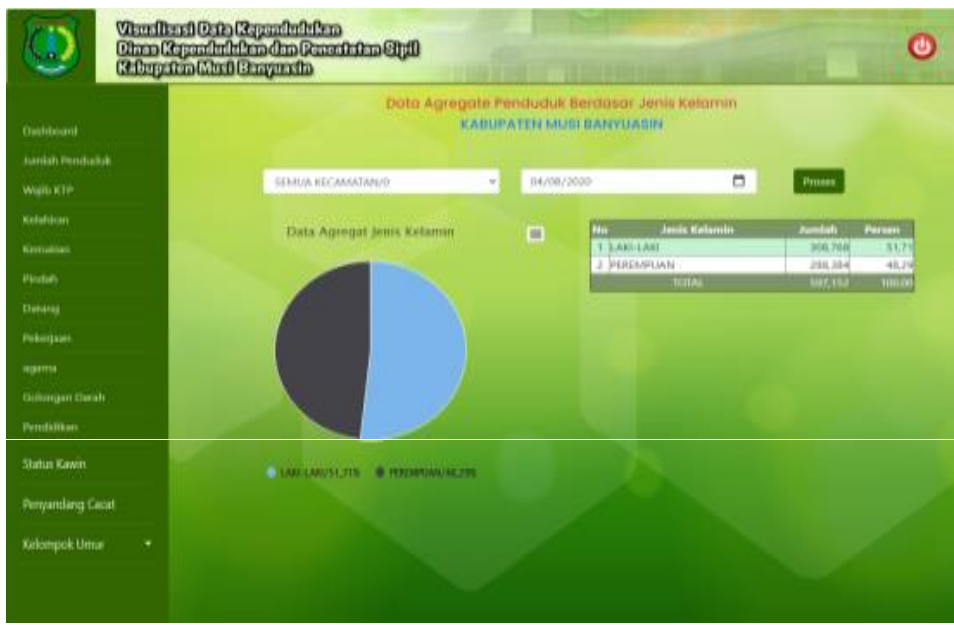

Gambar 3 Desain tampilan jumlah penduduk

\subsection{Menu Wajib KTP}

Pada menu Wajib KTP ini merupakan halaman untuk menampilkan data Wajib KTP perkecamatan dan perjenis kelamin yang ada pada Dinas Kependudukan dan Pencatatan Sipil Kabupaten Musi Banyuasin berbentuk grafik dan table baik data pada bulan lalu ataupun data bulan sekarang. Adapun menu Wajib KTP ini dapat di lihat pada gambar 4.

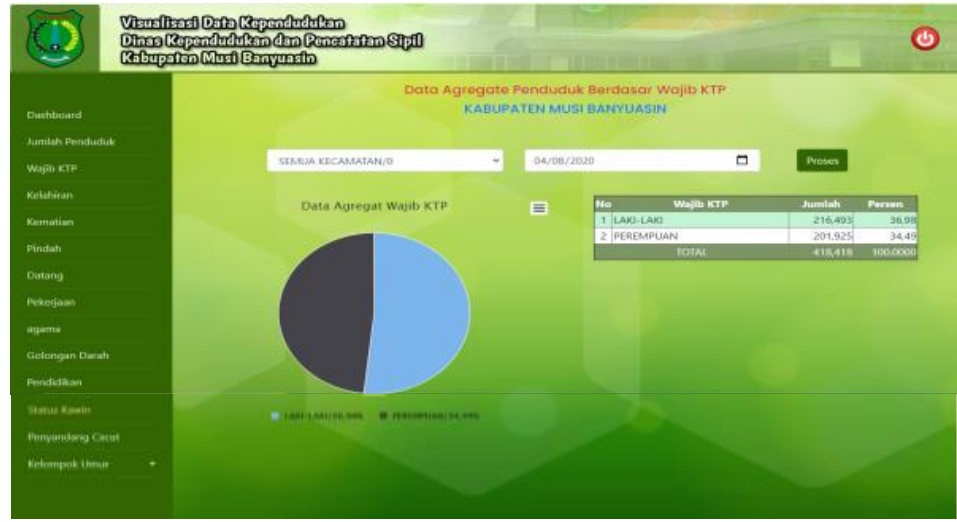

Gambar 4 Desain tampilan Wajib KTP

\subsection{Menu Kelahiran}

Pada menu kelahiran ini merupakan halaman untuk menampilkan data kelahiran perkecamatan dan perjenis kelamin yang ada pada Dinas 
Vol. 1, No. 3, September 2020 e-ISSN: 2775-2496

https://journal-computing.org/index.php/journal-cisa/index

Kependudukan dan Pencatatan Sipil Kabupaten Musi Banyuasin berbentuk grafik dan table baik data pada bulan lalu ataupun data bulan sekarang. Adapun menu kelahiran ini dapat di lihat pada gambar 5.

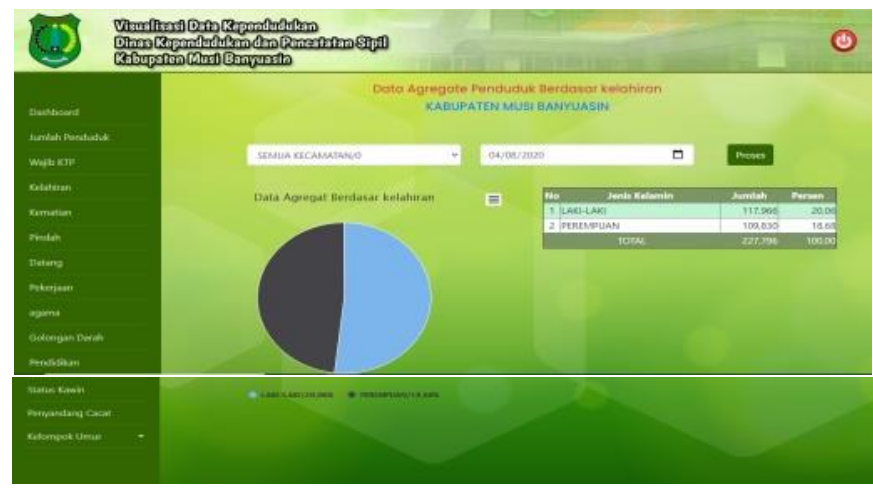

Gambar 5. Desain tampilan kelahiran

\subsection{Menu Kematian}

Pada menu kematian ini merupakan halaman untuk menampilkan data kelahiran perkecamatan dan perjenis kelamin yang ada pada Dinas Kependudukan dan Pencatatan Sipil Kabupaten Musi Banyuasin berbentuk grafik dan table baik data pada bulan lalu ataupun data bulan sekarang. Adapun menu kematian ini dapat di lihat pada gambar 6 .

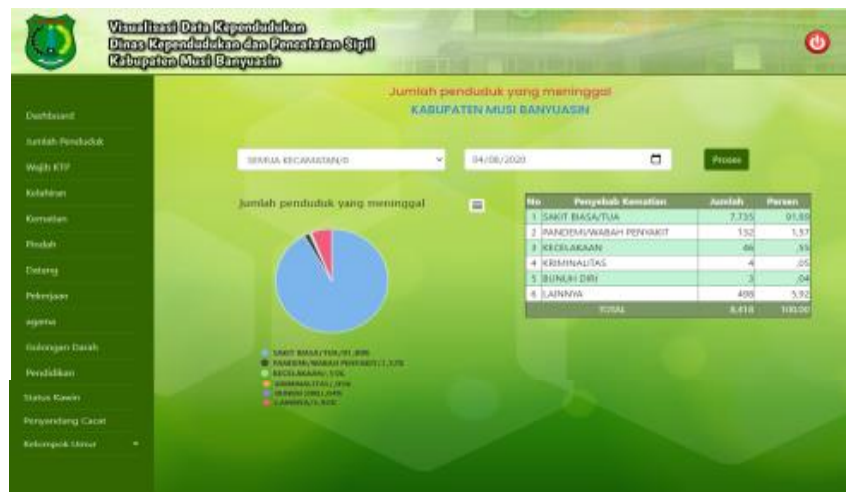

Gambar 6. Desain tampilan kematian

\subsection{Menu Pindah}

Pada menu kematian ini merupakan halaman untuk menampilkan data penduduk yang pindah perkecamatan dan perjenis kelamin yang ada 
Vol. 1, No. 3, September 2020 e-ISSN: 2775-2496

https://journal-computing.org/index.php/journal-cisa/index

pada Dinas Kependudukan dan Pencatatan Sipil Kabupaten Musi Banyuasin berbentuk grafik dan table baik data pada bulan lalu ataupun data bulan sekarang. Adapun menu pindah ini dapat di lihat pada gambar 7.

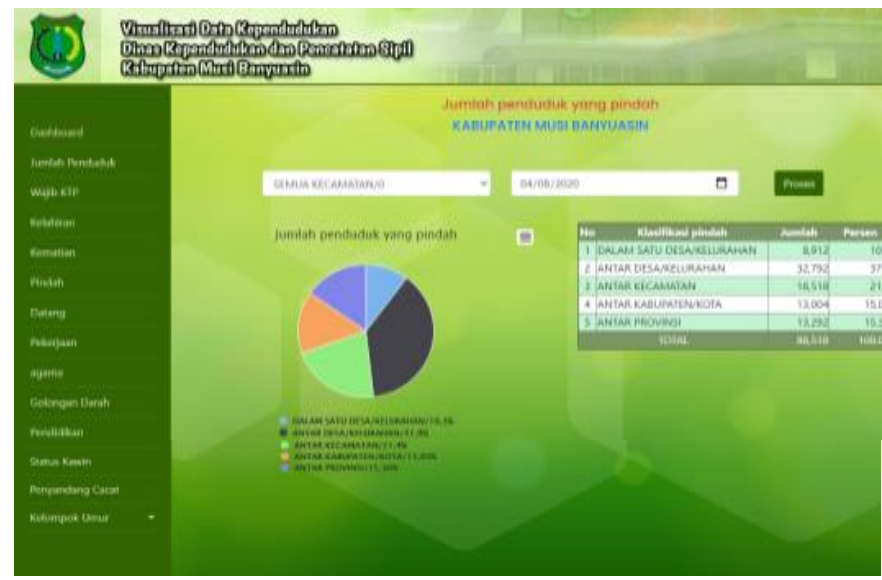

Gambar 7 Desain tampilan pindah

\subsection{Menu Datang}

Pada menu datang ini merupakan halaman untuk menampilkan data penduduk yang pindah perkecamatan dan perjenis kelamin yang ada pada Dinas Kependudukan dan Pencatatan Sipil Kabupaten Musi Banyuasin berbentuk grafik dan table baik data pada bulan lalu ataupun data bulan sekarang. Adapun menu datang ini dapat di lihat pada gambar 8.

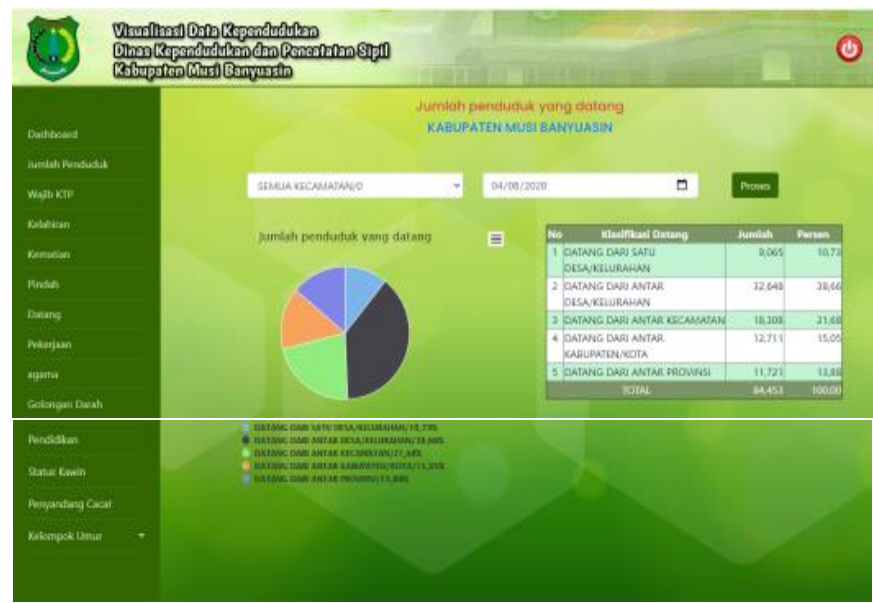

Gambar 8 Desain tampilan datang 
Vol. 1, No. 3, September 2020 e-ISSN: 2775-2496

https://journal-computing.org/index.php/journal-cisa/index

\subsection{Menu Pekerjaan}

Pada menu pekerjaan ini merupakan halaman untuk menampilkan data pekerjaan perkecamatan dan perjenis kelamin yang ada pada Dinas Kependudukan dan Pencatatan Sipil Kabupaten Musi Banyuasin berbentuk grafik dan table baik data pada bulan lalu ataupun data bulan sekarang. Adapun menu pekerjaan ini dapat di lihat pada gambar 9 .

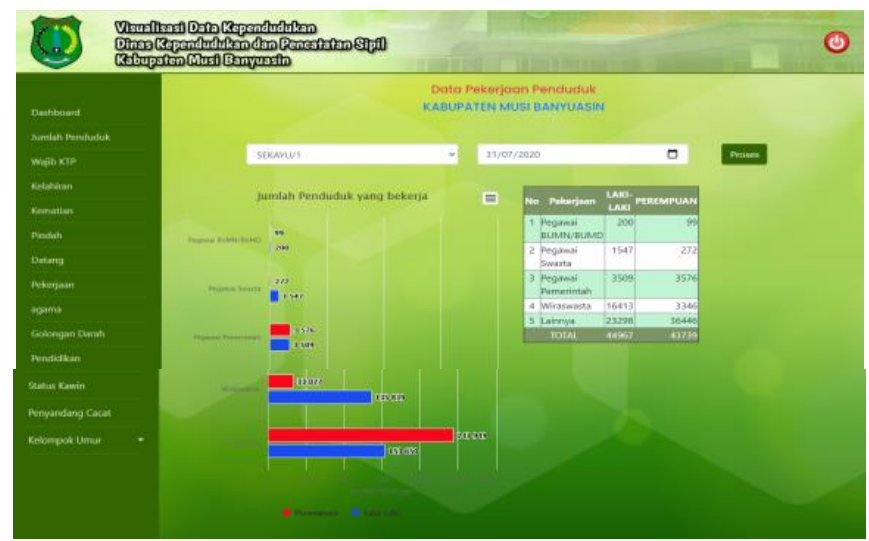

Gambar 4.9 Desain tampilan pekerjaan

\subsection{Menu Agama}

Pada menu agama ini merupakan halaman untuk menampilkan data agama perkecamatan dan perjenis kelamin yang ada pada Dinas Kependudukan dan Pencatatan Sipil Kabupaten Musi Banyuasin berbentuk grafik dan table baik data pada bulan lalu ataupun data bulan sekarang. Adapun menu agama ini dapat di lihat pada gambar 10.

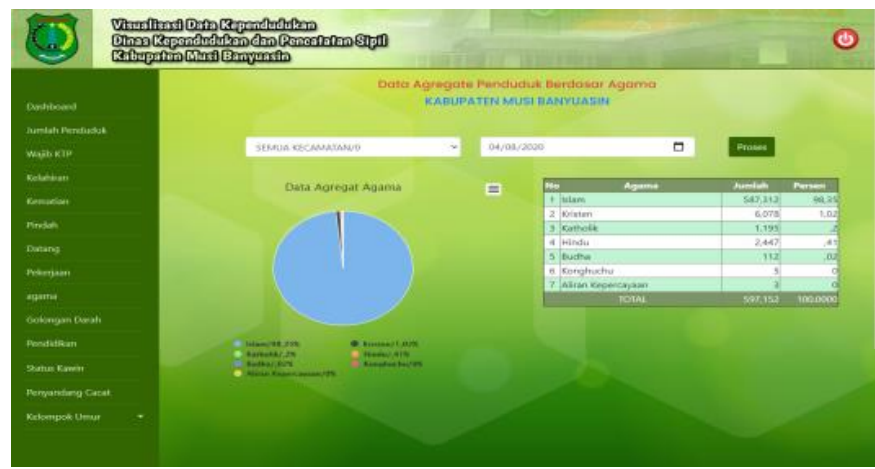

Gambar 4.10 Desain tampilan agama 
Vol. 1, No. 3, September 2020 e-ISSN: 2775-2496

https://journal-computing.org/index.php/journal-cisa/index

\subsection{Menu Golongan Darah}

Pada menu golongan darah ini merupakan halaman untuk menampilkan data golongan darah perkecamatan dan perjenis kelamin yang ada pada Dinas Kependudukan dan Pencatatan Sipil Kabupaten Musi Banyuasin berbentuk grafik dan table baik data pada bulan lalu ataupun data bulan sekarang. Adapun menu golongan darah ini dapat di lihat pada gambar 11.

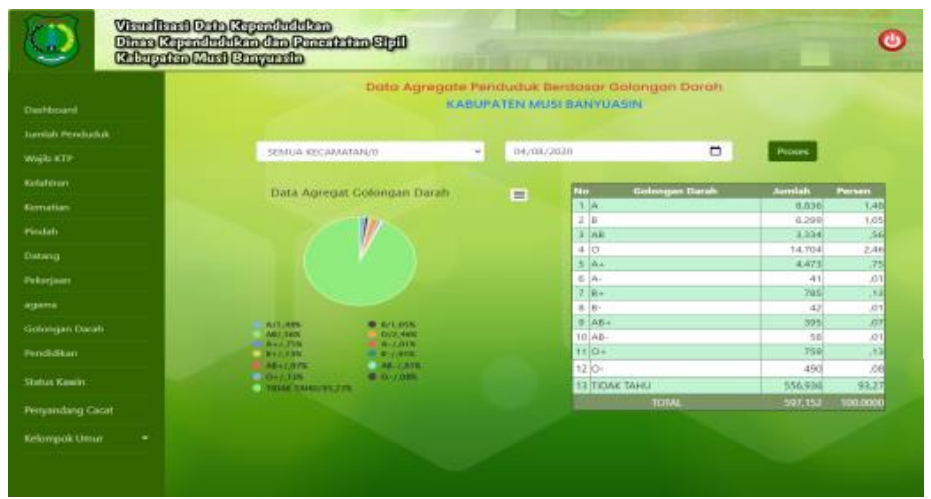

Gambar 4.11 Desain tampilan golongan darah

\subsection{Menu Pendidikan}

Pada menu pendidikan ini merupakan halaman untuk menampilkan data pendidikan perkecamatan dan perjenis kelamin yang ada pada Dinas Kependudukan dan Pencatatan Sipil Kabupaten Musi Banyuasin berbentuk grafik dan table baik data pada bulan lalu ataupun data bulan sekarang. Adapun menu pendidikan ini dapat di lihat pada gambar 12 .

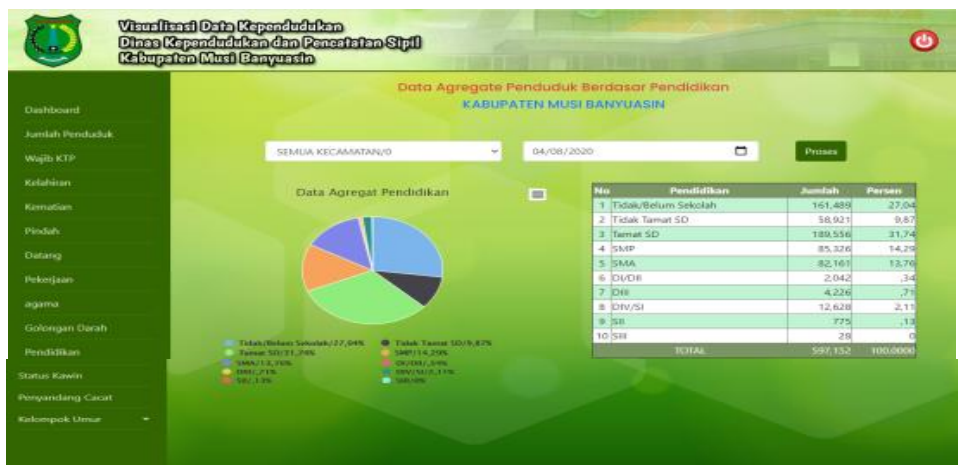

Gambar 12 Desain tampilan pendidikan 
Vol. 1, No. 3, September 2020 e-ISSN: 2775-2496

https://journal-computing.org/index.php/journal-cisa/index

\subsection{Menu Status Kawin}

Pada menu status kawin ini merupakan halaman untuk menampilkan data status kawin perkecamatan dan perjenis kelamin yang ada pada Dinas Kependudukan dan Pencatatan Sipil Kabupaten Musi Banyuasin berbentuk grafik dan table baik data pada bulan lalu ataupun data bulan sekarang. Adapun menu status kawin ini dapat di lihat pada gambar 13.

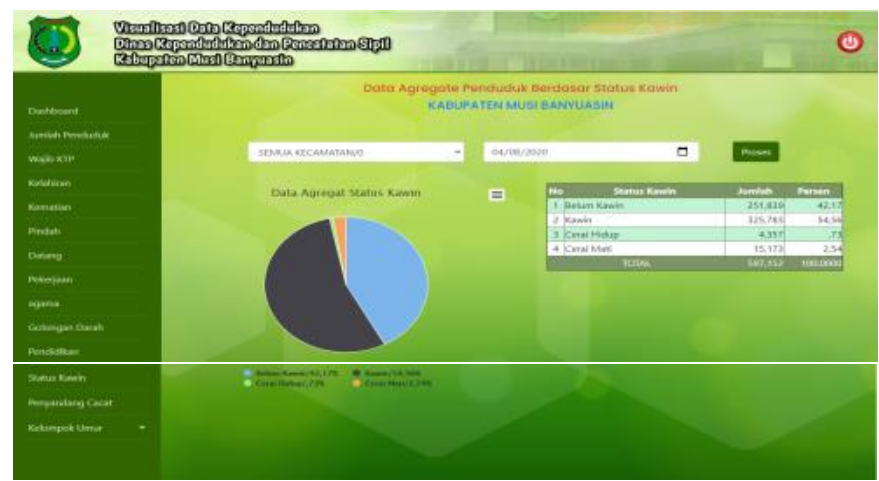

Gambar 13 Desain tampilan status kawin

\subsection{Menu Penyandang Cacat}

Pada menu penyandang cacat ini merupakan halaman untuk menampilkan data penyandang cacat perkecamatan dan perjenis kelamin yang ada pada Dinas Kependudukan dan Pencatatan Sipil Kabupaten Musi Banyuasin berbentuk grafik dan table baik data pada bulan lalu ataupun data bulan sekarang. Adapun menu penyandang cacat ini dapat di lihat pada gambar 14 .

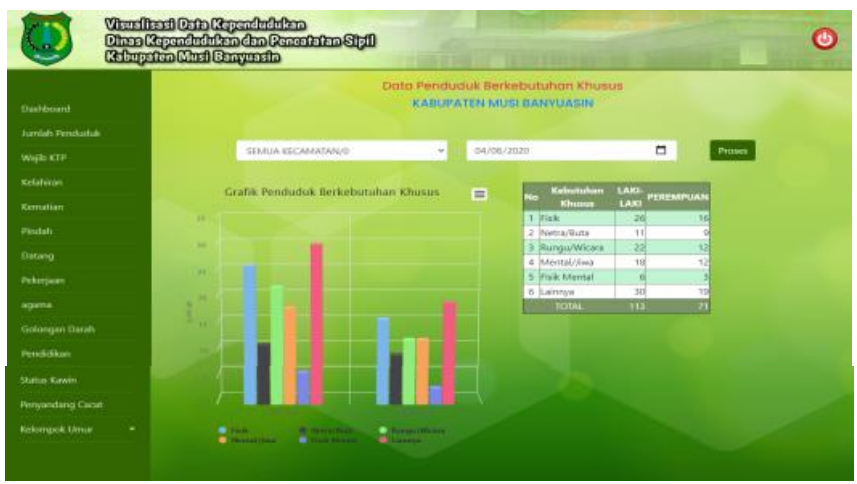

Gambar 14 Desain tampilan penyandang cacat 
Vol. 1, No. 3, September 2020 e-ISSN: 2775-2496

https://journal-computing.org/index.php/journal-cisa/index

\subsection{Kelompok Umur \\ 1) Menu Semua Umur}

Pada menu semua umur ini merupakan halaman untuk menampilkan data semua umur perkecamatan dan perjenis kelamin yang ada pada Dinas Kependudukan dan Pencatatan Sipil Kabupaten Musi Banyuasin berbentuk grafik dan table baik data pada bulan lalu ataupun data bulan sekarang. dalam hal ini tentunya memudahkan pengguna untuk menggunakan data tersebut. Adapun menu semua umur ini dapat di lihat pada gambar 15.

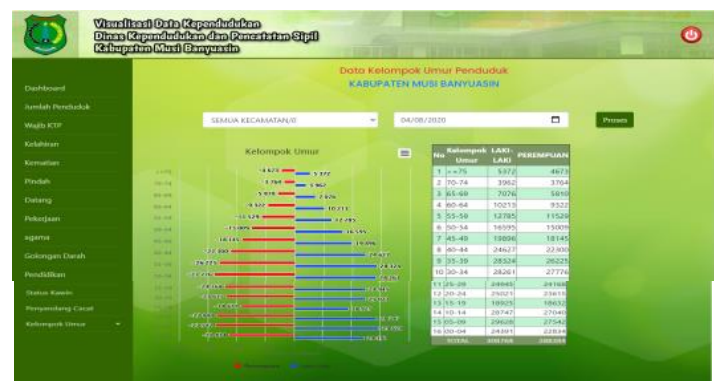

Gambar 15 Desain tampilan semua umur

\section{2) Menu Umur 0 Sampai 17 Tahun}

Pada menu umur 0 sampai 17 tahun ini merupakan halaman untuk menampilkan data umur 0 sampai 17 tahun perkecamatan dan perjenis kelamin yang ada pada Dinas Kependudukan dan Pencatatan Sipil Kabupaten Musi Banyuasin berbentuk grafik dan table baik data pada bulan lalu ataupun data bulan sekarang. dalam hal ini tentunya memudahkan pengguna untuk menggunakan data tersebut. Adapun menu umur 0 sampai 17 tahun ini dapat di lihat pada gambar 16 .

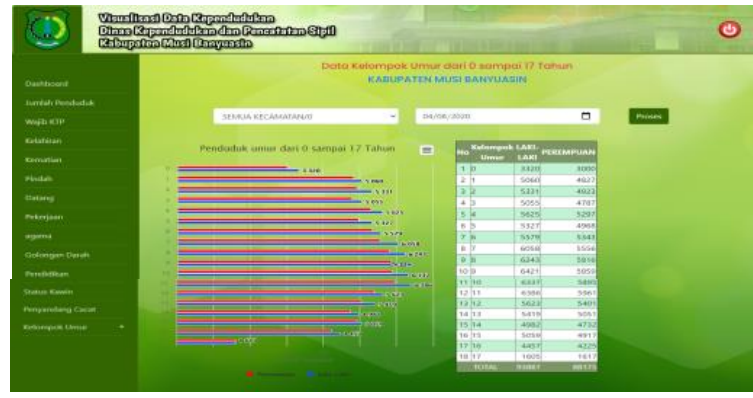

Gambar 16 Desain tampilan umur 0 sampai 17 tahun 


\section{KESIMPULAN}

Hasil penelitian serta pembahasan mengenai visualisasi data kependudukan pada Dinas Kependudukan dan Pencatatan Sipil Kabupaten Musi Banyuasin, dapat disimpulkan sebagai berikut:

1) Dengan menggunakan metode Extreme Programming penelitian ini telah berhasil menghasilkan dashboard data kependudukan

2) "Aplikasi visualisasi data kependudukan pada Dinas Kependudukan dan Pencatatan Sipil Kabupaten Musi Banyuasin ini telah berhasil dibangun sehingga dapat mengelola data kependudukan dalam bentuk grafik dan tabel."

3) Aplikasi visualisasi data kependudukan ini telah berhasil di uji dengan metode BlackBox Testing.

4) Hasil dari pengujian visualisasi data kependudukan pada Dinas Kependudukan dan Pencatatan Sipil Kabupaten Musi Banyuasin berhasil dan bagus.

\section{DAFTAR PUSTAKA}

Anhar. (n.d.). PHP \& MySql Secara Otodidak. MediaKita.

Binarso, Y. A., \& Sarwoko, E. A. (2012). Journal of Informatics and Technology, Vol 1, No 1, Tahun 2012, p 72-84 http://ejournals1.undip.ac.id/index.php/joint.1(1), 13.

Budiarti, Y., \& Risyanto, R. (2020). Implementasi Metode Extreme Programming Untuk Merancang Sistem Informasi Pendaftaran Siswa Baru Berbasis Web Pada Smk Multimedia Mandiri Jakarta. Jurnal Informatika, 8(1), $1-9$. https://doi.org/10.36987/informatika.v8i1.1402

Destiningrum, M., \& Adrian, Q. J. (2017). Sistem Informasi Penjadwalan Dokter Berbassis Web Dengan Menggunakan Framework Codeigniter (Studi Kasus: Rumah Sakit Yukum Medical Centre). Jurnal Teknoinfo, 11(2), 30. https://doi.org/10.33365/jti.v11i2.24

Efendi, R. D. (n.d.). Fakultas Sains Dan Teknologi Universitas Islam Negeri Sultan Syarif Kasim Riau Pekanbaru. 81.

Lestariningsih, E., Ardhianto, E., Handoko, W. T., \& Supriyanto, E. (2016). Visualisasi Data Penduduk Berbasis Web di Kelurahan Mranggen 
Vol. 1, No. 3, September 2020 e-ISSN: 2775-2496

https://journal-computing.org/index.php/journal-cisa/index

Kecamatan Mranggen Kabupaten Demak menggunakan Highcart 5.0.6.21, 8 .

Pahlevi, O., Mulyani, A., \& Khoir, M. (2018). Sistem informasi inventori barang menggunakan metode object oriented di pt. Livaza teknologi indonesia jakarta. 5(1), 9.

Putra. (2020, January 31). Pengertian Internet: Sejarah, Fungsi, Manfaat \& Dampak Positif Negatif. Salamadian. https://salamadian.com/pengertian-internet/

Rusdiana, L. (2018). Extreme Programming untuk rancang bangun aplikasi pengelolaan surat keterangan kependudukan. Register: Jurnal Ilmiah Teknologi Sistem Informasi, 4(1), 49. https://doi.org/10.26594/register.v4i1.1191

School, D. (2017, March 11). Apa Itu ORACLE ? Kursus Web Programming. https://kursuswebprogramming.com/apa-itu-oracle/

Setiawan, A. A., Johan. (2018). Metodologi penelitian kualitatif. CV Jejak (Jejak Publisher).

Silvana, M., Akbar, R., \& Tifani, R. (n.d.). Penerapan Dashboard System Di Perpustakaan Universitas Andalas Menggunakan Tableau Public. 6.

Supardin, D., Bunyamin, H., \& Sekolah Tinggi Teknologi Garut. (2016). Aplikasi Pengelolaan Data Penduduk di Kantor Kelurahan Margawati. Jurnal Algoritma, 12(2), 410-416. https://doi.org/10.33364/algoritma/v.12-2.410

Swara, G. Y., Kom, M., \& Pebriadi, Y. (2016). Rekayasa Perangkat Lunak Pemesanan Tiket Bioskop Berbasis Web. 4(2), 13. 